\title{
The Human Quest for Happiness and Meaning: Old and New Perspectives. Religious, Philosophical, and Literary Reflections from the Past as a Platform for Our Future - St. Augustine, Boethius, and Gautier de Coincy
}

\author{
By Albrecht Classen*
}

\begin{abstract}
Despite much ignorance (deliberate and accidental) and neglect, pre-modern literature, philosophy, and theology continue to matter greatly for us today. The quest for human happiness is neverending, and each generation seems to go through the same process. But instead of re-inventing the proverbial wheel, we can draw on most influential and meaningful observations made already in late antiquity and the Middle Ages regarding how to pursue a good and hence a happy life. This paper examines the relevant treatises by St. Augustine and Boethius (late antiquity), and a religious tale by Gautier de Coincy (early thirteenth century). Each one of them already discussed at great length and in most convincing manner how human beings can work their way through false concepts and illusions and reach a higher level of epistemology and spirituality, expressed through the terms "happiness" and "goodness."
\end{abstract}

\section{Introduction}

The Quest and Literature

Ultimately, it seems, almost all efforts by people throughout time and all over the world focus on one and the same goal, as simple as that might sound: happiness. There is no purpose to life at all if misery and unhappiness rule and the daily routine consists of nothing but drudgery and pain that are not sustained by any relevance or meaning. Wherever we look, whatever text we read, whatever discourse we listen to, and however we ourselves try to make our own existence meaningful and hence successful, the struggle goes on and seems to be infinite. Each generation embarks on the same quest, as if all past teachings might not have had enough meaning and as if the answers only wait for us in the future. Over and over again the same question is being raised, and the effort is renewed, as if we are moving in an infinite cycle without achieving finally the higher plateau from where we might distance ourselves more wisely from past attempts and reach for the more spiritual perception of what it truly means to be happy.

Are we then Sisyphus or Ulysses? What goal do we pursue during our

*University Distinguished Professor, The University of Arizona, USA. 
lifetime? Does our ship have the necessary anchor? To think about just one example, Gahmuret in Wolfram von Eschenbach's Parzival (ca. 1205) seems to miss his own goal, or purpose, despite his ubiquitous use of the anchor as an icon in his coat of arms, which hence might explain his unsteadiness, his uncontrollable desire to find new adventures, to meet new women, to marry and yet to depart for good. He almost seems to be the postmodern person, being restless, unsteady, indeterminate, almost hopeless since he does not even know what he might be looking for in his life.

Where does his happiness rest, and hence, where does our own happiness reside? It takes the entire romance for his son Parzival to learn the true message, to ask the right question, to liberate the Grail world from its doom, and hence to achieve a degree of happiness which applies to everyone because it is not located within the protagonist, but in the Grail. By freeing the world from its misery, by achieving the long-awaited accomplishment, showing compassion and demonstrating communicative skills, establishing a new community in a collaborative and comprehensive way, Parzival gains happiness, and with him the entire world. In a way, Parzival thus proves to be a literary "messiah," without pursuing a specifically religious goal. ${ }^{1}$

Dante Alighieri's Divina Commedia (ca. 1305-1325) immediately comes to mind as well, but then also John Milton's Paradise Lost (1667) or Johann Wolfgang Goethe's Faust (first printed in 1790), where the quest for the ultimate answer-whatever that might be in religious or epistemological terms-determines all human endeavors. ${ }^{2}$ In fact, here we can easily recognize one of the central tenets that underlie the occupation with literature in the first place, since it provides meaningful models of how individuals have found their way through life and might have accomplished their task of living to the fullest and deepest, despite, or perhaps rather just because of the many struggles which they had to overcome. With the term literature we do not limit ourselves to the contemporary notion of the "fictional" account; instead, as a medievalist I incorporate here all efforts to come to terms with the human spirit and the quest for happiness in narrative terms. Despite huge genre differences, we are called upon to study works as diverse as Marcus Aurelius's (121-180) Meditations and Voltaire' s Candide (1759).

1. Eschenbach von Wolfram, Parzival and Titurel, trans. and notes Cyril Edwards (Oxford: Oxford University Press, 2006).

2. Charles Dahlberg, The Literature of Unlikeness (Hanover and London: University Press of New England, 1988); Jonathan Ullyot, The Medieval Presence in Modernist Literature: The Quest to Fail (Cambridge: Cambridge University Press, 2015). 


\section{The Meaning of Literature for the Search for Happiness}

The purpose of the present paper, however, is not to carry the proverbial "owls to Athens" or "coal to Newcastle" by insisting on the canonical value of medieval literature for the modern student generation. The historical veneer of Boccaccio's Decameron (ca. 1351) or Geoffrey Chaucer's Canterbury Tales (ca. 1400) would rescue today those masterpieces as little from oblivion as the works by Wolfram von Eschenbach (Parzival, ca. 1205), Marie de France (ca. 1170-1190), Juan Ruiz (El libro de buen amor, ca. 1350), or the plethora of Icelandic sagas (e.g., Njál's Saga, ca. 1300). But by the same token, even literary giants such as François Rabelais, William Shakespeare, Gotthold Ephraim Lessing, Jane Austin, Émile Zola, Fyodor Dostoyevsky, Thomas Mann, Bertolt Brecht etc. would also easily fall away and disappear in the dust of history if their works did not contain something special which we moderns might be missing or cannot retrieve on our own. In short, the quest for happiness is on-going, and each time we put down a book in the belief to have grasped the direction we have to take for our future, then the very hope seems to disappear as a most fleeting experience, which then makes it necessary to keep reading and reflecting as an ever on-going process.

Happiness, much discussed and defined in a myriad fashions both in the past and present, proves to be fleeting, and yet it is always near-by and within our reach, except that we as human beings have to struggle hard to achieve it for ourselves all the time. But where do we start, and how do we approach this task? What role do the humanities play in that regard? Can literature or philosophy offer a panacea, that is, critical narratives from the past? Of course, they do, as countless writers have already confirmed throughout time, otherwise we would not have Humanities departments at universities across the world, or would not have libraries everywhere as storehouses of human wisdom and understanding. ${ }^{3}$ Curiously, as to be expected, not one of those millions of books contains the secret, ultimate, finite message about how to establish happiness. Each individual has to go through his/her own learning and growth process, but reading about past experiences, reflections, visions, and illuminations represents one of the crucial vehicles to achieve that goal.

There is no doubt about the fundamental truth and value of literature

3. Albrecht Classen, "The Quest for Knowledge Within Medieval Literary Discourse: The Metaphysical and Philosophical Meaning of Love," in Words of Love and Love of Words in the Middle Ages and the Renaissance, ed. Albrecht Classen (Tempe, AZ: Arizona Center for Medieval and Renaissance Studies, 2008); Classen, "The Meaning of Literature - A Challenge of Modern Times - What the Sciences Cannot Teach Us. With Emphasis on the Gesta Romanorum, Boccaccio's Decameron, Lessing's Nathan the Wise, and the Verse Narratives by Heinrich Kaufringer," Humanities 5, no. 24 (2016), accessed January 8, 2017, DOI:10.3390/h5020024. 
and philosophy, whether from the Middle Ages or the contemporary time. Countless scholars and also ordinary people, hence, readers all over the world have confirmed that universal truth, but I would like to add that the poetic text can powerfully serve as a lens through which we can gaze more deeply into the heart of all human existence. This takes us back to the fundamental issue of what constitutes happiness. As I want to argue here, for specific reasons drawing primarily from pre-modern treatises, poets, philosophers, and theologians have regularly offered models of how human life could be maintained and organized in a good, if not ideal manner. Their texts naturally and intentionally tend to over-dramatize individual situations, a strategy which simply serves to understand better the basic conflicts, tensions, issues, and questions presented here. The analysis subsequently makes it possible to grasp the problems all humans face, and to gain insight into possible solutions, strategies, and operations in our own lives, today and in the future. I suggest here that we can gain tremendously from the discourse on happiness as it was carried out already in late antiquity for our own purposes. I will illustrate this through a critical analysis especially of two texts by some of the most influential thinkers of their time who have demonstrated how much old voices can promise ever fresh insights in such broad issues such as happiness, and then conclude with the interpretation of one thirteenth-century religious narratives which contains a surprising answer as to how to find individual happiness.

\section{But What Is Happiness?}

Overall, there are, maybe surprisingly, not really too many aspects determining human life, such as love, the quest for God, fear of death, violence, curiosity, and values in general. It is, not surprisingly, not enough just to live materially, since this would entail nothing but eating, digesting, sleeping, and working. We need meaning, and hence happiness, issues which literature and related works have regularly addressed throughout time. What happiness might entail, however, is a highly complex and difficult topic that has been investigated from countless perspectives by scholars and thinkers since antiquity. There are many approaches possible, viewing happiness as a matter of psychology, sociology, economy, physiology, religion, philosophy, and so forth. Our libraries are filled with respective studies, and yet in this huge cacophony of voices nothing seems to matter any longer because the multiplicity of recommendations, ideas, suggestions, proposals, strategies, and pursuits is simply overwhelming, suggesting that anything goes that might promise practical avenues to achieve happiness after all.

Only in the last year or so numerous new books have appeared focused on and struggling with this issue. Peter Roberts, for instance, now 
underscores, drawing on the work of Søren Kierkegaard, Miguel de Unamuno, Fyodor Dostoevsky, Simone Weil, Paulo Freire, and others, how much education plays a central role in achieving happiness, providing the learner with a plethora of options to search and probe for him/herself what this world and our existence within might mean altogether. ${ }^{4}$ Mick Power suggests that a positive mind-set, a constructive approach to all life conditions would make it possible to achieve happiness, especially if we embrace both negative and positive emotions and experiences. ${ }^{5}$ There are many degrees of happiness in this world, both past and present, depending on cultural, economic, but especially philosophical-religious conditions, as Roman Cybriwsky now suggests. ${ }^{6}$ Wealth and monetary riches are certainly no guarantee for happiness, and political power, rulership, military or otherwise violent form of control only insinuate happiness, but are further away from it than anything else. In other words, we in the West are often more disconnected from happiness than people in the so-called "third world," as unfair and inappropriate as this term might be. Emma Seppälä suggests that one way of achieving personal happiness consists of operating more reasonably with one's inner energies, both physical and spiritual. ${ }^{7}$

The contributors to Behavioral Economics of Preferences, Choices, and Happiness now outline how much a reasonable management of time, the establishment of self-control, and a solid grip on our own behavioral concepts might bring about happiness. ${ }^{8}$ Others opine that we can achieve happiness as adults if we do not lose the connection to our childhood memories, ${ }^{9}$ and then there are legal authors who outline ways to achieve happiness through successful court trials. ${ }^{10}$ For Stefano Bartolini, Ennio Bilancini, Luigino Bruni, and Pier Luigi the path toward happiness consists in good policy making, ${ }^{11}$

4. Peter Roberts, Happiness, Hope, and Despair: Rethinking the Role of Education (New York: Peter Lang, 2016), 43.

5. Mick Power, Understanding Happiness: A Critical Review of Positive Psychology (London: Routledge, 2016).

6. Roman Adrian Cybriwsky, Global Happiness: A Guide to the Most Contented (and Discontented) Places Around the Globe (Santa Barbara, CA: Greenwood, 2016).

7. Emma Seppälä, The Happiness Track: How to Apply the Science of Happiness to Accelerate Your Success (New York: HarperOne, 2016).

8. Shinsuke Ikeda, Hideaki Kiyoshi Kato, Fumio Ohtake, and Yoshiro Tsutsui, ed., Behavioral Economics of Preferences, Choices, and Happiness (Tokyo: Springer Japan, 2016), DOI: 10.1007/978-4-431-55402-8_1.

9. Catherine Newman, Catastrophic Happiness: Finding Joy in Childhood's Messy Years (New York: Little, Brown and Company, 2016).

10. Lawrence D. Rosenberg, Deborah A. Topol, and David A. Soley, The Trial Lawyer's Guide to Success and Happiness (Chicago: American Bar Association, 2016).

11. Stefano Bartolini, Ennio Bilancini, Luigino Bruni, and Pier Luigi Porta, Policies for Happiness (Oxford: Oxford University Press, 2016). 
while Shannon M. Suldo explores how students can reach that goal in their own lives. ${ }^{12}$ Following some authors, happiness is a subject that one can learn through a systematic study, as if it were a matter outside of oneself, like mathematics, medicine, or theology. ${ }^{13}$ There is a virtual flood of pertinent titles, some scholarly in nature, others aiming at the more general reader, and it seems as if the topic of happiness has currently attracted every academic discipline, both medicine and philosophy, both psychology and history.

Does this mean that we have suddenly discovered that people need happiness and that this quest can be pursued in a scientific-psychological manner? Is this really a new issue characteristic of the twenty-first century? Hardly so, but it seems as if we are re-inventing the wheel, or that we are in a constant process of reflecting on one of the most important but also most elusive topics in human life because we are not able or willing to learn from previous thinkers. No one would be able to blame these many different contemporary authors probing on their own what the meaning of happiness might be from their perspective and to what extent they could contribute to their readers' happiness. We are dealing here with one feature of a huge, probably universal discourse, which even a handbook on happiness cannot simply come to terms with. ${ }^{14}$

Older approaches, however, which at times seem to be much more important, receive much less attention, perhaps simply out of ignorance, perhaps out of convenience. Since antiquity philosophers, theologians, and poets have already investigated the nature and quality of happiness, and probed multiple avenues for the individual to create happiness for him/ herself. We might, of course, dismiss those older perspectives, claiming that

12. Shannon M. Suldo, Promoting Student Happiness: Positive Psychology Interventions in Schools (New York: Guilford Press, 2016).

13. Katherine Center, Happiness for Beginners (New York: St. Martin's Griffin, 2015).

14. Ilona Boniwell, Susan A. David, and Amanda Conley Ayers, ed., The Oxford Handbook of Happiness (Oxford: Oxford University Press, 2013), DOI: 10.1093/oxford hb/9780199557257.001.0001; see also, Dieter Thomä, Christoph Henning, and Olivia Mitscherlich-Schönherr, ed., Glück: ein interdisziplinäres Handbuch (Happiness: An interdisciplinary manual) (Stuttgart: Metzler, 2011), DOI: 10.1007/978-3-476-00372-0. There are countless other guidebooks for how to achieve individual happiness, written by religious leaders, ethnicists, philosophers, and poets. All these publications might be useful and important, but for us they indicate, above all, how much the quest for human happiness has dominated much of all intellectual endeavors since antiquity and how much, in particular, people in our post-modern day and age are becoming more desperate than ever before in their seemingly futile search for happiness although we have more machines helping in our lives today than all other generations before us. But no convenience, speed, interconnectedness, and mechanical power can produce happiness outside of ourselves since happiness is something most intimately human, and then also divine. 
they carry little significance for us today because all of our life circumstances have changed. However, late antique and medieval thinkers were already dwarves standing on the shoulders of giants, and the same then applies to late medieval and early modern philosophers, for instance. Furthermore, much of western thinking, the entire value system, morality and ethics derive from those original sources and have been filtered down to our own time, whether we remember that or are even aware of it or not.

Subsequently, as I want to argue in the present paper, the gaze backwards will allow us to reflect once again on some of the most important intellectual contributions from the previous world and to draw from their profound insights. The huge respect which theologians such as St. Augustine and philosophers such as Boethius have enjoyed throughout the centuries vouchsafe for their great authority even, if not specifically, for the topic of happiness. I will draw from both their insights and will argue that past experiences and ideas continue to hold great significance for us today, which justifies and legitimizes our constant effort to investigate and research the Middle Ages, for instance, as a springboard for contemporary quests. There we find the roots of our own existence, and the metaphorical leaves of our present day and age directly receive their water by way of an intricate pumping system going all the way down to the roots. Ignoring those roots, however, would endanger the survival of the leaves - the future cannot come about without a full understanding and appreciation of the past. In this approach I will at first draw not on literary texts, but on those by a theologian and a philosopher. However, as we will observe subsequently, both became foundational for the literature throughout the entire Middle Ages and well beyond and so deserve to be included here in the first place.

One and the same issue constitutes the central quest, which we best identify as "wisdom." As the Austrian author Karl-Heinrich Waggerl observed in his Wagrainer Tagebuch (1936; Diary of Wagrain), people grow in the course of time in terms of skills, know-how, and mechanical arts, but with regard to wisdom there is little progress to report, on the contrary. This insight probably applies to our own day and age with all of the computers available everywhere, internet communication, and cell phone technology, but with less and less true wisdom about the spiritual dimension of all things. ${ }^{15}$ Waggerl, unfortunately, probably because of his naive association with the Nazis, no longer enjoys the critical respect by German-language scholarship, but this would not have any impact on our evaluation of his significant life philosophy, which ultimately mirrors what intellectual giants long before him had formulated already in their own way.

15. Karl Heinrich Waggerl, Wagrainer Tagebuch. Gesammelte Werke, 2 (Bookmark and Share Collected Works, 2) (Salzburg: Otto Müller, 1987), 58. 


\section{Happiness and the Middle Ages}

What I am suggesting in this paper has wider implications. I will not only address the question regarding the nature and character of happiness; instead I will investigate both more globally and more specifically to what extent the medieval world continues to exert an influence on us today, what its meaning might be in our present time, and how we could profit from that past world for the understanding of the present and future world we are living in. In essence, the central concern focuses on how to explain to the current generation why the Middle Ages still matter deeply for us, both in general terms for the larger audience, and for the academy.

Numerous scholars have illuminated this issue already a number of times through a close reading of specific texts, demonstrating how much we are facing actually universal issues that at times have been answered, so it seems, already very concretely and in a highly illuminating fashion long before, such as in medieval romances, love poetry, heroic epics, didactic verses, and other genres. ${ }^{16}$ Many studies have been dedicated to contemporary films and art works, to literary texts and craft objects with medieval themes, but those tend to take a rather light route via the general need for fantasy and playfulness. We all know about J. R. R. Tolkien's famous Lord of the Ring and J. K. Rowling's stupendously popular book series Harry Potter. Then there is the Society for Creative Anachronism, especially in North America, and there are countless cities in Europe (but also in the US) where Renaissance or medieval festivals attract the masses. Tourism has long discovered the great impact which medieval sites such as castles have on paying customers, and if there

16. Ina Karg, ...«und waz si guoter lêre wernt»...: Mittelalterliche Literatur und heutige Literaturdidaktik- Versuch einer Kooperation (... what are good instructions ...: Medieval Literature and Modern Literary Didactics: Attempt of a Cooperation) (Frankfurt am Main: Peter Lang, 1998); Nine Miedema and Andrea Sieber, ed., Zurück zum Mittelalter: Neue Perspektiven für den Deutschunterricht (Back to the Middle Ages: New Perspectives for Teaching of German Literature) (Frankfurt am Main: Peter Lang, 2013); Albrecht Classen, "What do they mean for us today? Medieval Literature and Philosophy at the End of the Twentieth Century. Boethius, John of Salisbury, Abelard, and Christine de Pizan," Mediaevistik 12 (1999): 185-208; Classen, "Medieval Studies within German Studies: The Nibelungenlied and Hartmann von Aue's Der arme Heinrich)," in Taking Stock of German Studies in the United States: The New Millennium, ed. Rachel Halverston and Carol Anne Costabile Heming (Rochester, NY: Camden House, 2015); Classen, "Friendship, Death, and Boethian Philosophy in the High Middle Ages: The Meaning of the Past for Our Present and Future. With a Special Focus on Lawrence of Durham's Consolatio (1141) and Aelred of Rievaulx's De Spirituali Amicitia (1164-1167)," Medieval Perspectives 28 (2013); Classen, "The Meaning of Literature"; Simon R. Doubleday and David Coleman, ed., In the Light of Medieval Spain: Islam, the West, and the Relevance of the Past (New York: Palgrave Macmillan, 2008). 
are no real surviving castles, then fake imitations substitute for the authentic buildings, in the vein of Hollywood and Walt Disney. Medieval feasts represent major events for the contemporary traveler, providing them with a sense of living history, a Romantic notion of the past, and a faint idea about what a cultural and historical identity might mean in reality - such as castle Gruyère in Switzerland or castle Bunratty in Ireland. Contemporary video games, card games, fantasy novels, and many other media continue to confirm the astounding popularity and actual significance of the Middle Ages for the post-modern world. But instead of dealing with common dreams about the past in a playful manner, my purpose is focused on the question how pre-modern reflections and insights might help us today to find our way (back) to happiness as the ideal concept underlying all human existence.

\section{Ancient Philosophy and Happiness: Aristotle}

Instead of limiting myself to literary evidence, I will go one step further and pursue also philosophical and religious perspectives Without falling into the trap of repeating popular opinions, we can certainly claim that many medieval thinkers and intellectuals had already ruminated on basic human issues that continue to concern us deeply, more often than not offering perspectives and insights that carry deep meaning throughout the ages. ${ }^{17} \mathrm{We}$ have to avoid the danger of arguing anachronistically, quite naturally, but there are truly many reasons to pay close attention to some of those voices that, because of their far-reaching impact, had laid the foundation of Western civilization and hence continue to determine our outlook and value system today. ${ }^{18}$

While contemporary authors intensively probe the meaning of happiness from their own professional and personal perspective, the issue has already been addressed a very long time ago in a most profound fashion, both by

17. Albrecht Classen, "The Literary Treatment of the Ineffable: Mechthild von Magdeburg, Margaret Ebner, Agnes Blannbekin," Studies in Spirituality 8 (1998); Classen, "Worldly Love - Spiritual Love. The Dialectics of Courtly Love in the Middle Ages," Studies in Spirituality 11 (2001); Classen, "The Dialectics of Mystical Love in the Middle Ages: Violence/Pain and Divine Love in the Mystical Visions of Mechthild of Magdeburg and Marguerite Porète," Studies in Spirituality 20 (2010); Classen, "Mystical Visions and Spiritual Health: Medieval Mysticism As A Platform for the Exploration of Human Spirituality and Happiness: The Transcendence of the Body in the Quest for the Godhead - A Message for Us Today?," Studies in Spirituality 25 (2015). See also Krijn Pansters, Franciscan Virtue: Spiritual Growth and the Virtues in Franciscan Literature and Instruction of the Thirteenth Century (Leiden and Boston: Brill, 2012).

18. Classen, ed., Medieval Answers to Modern Problems (San Diego: Cognella Inc. \& University Readers, 2012; rev. ed. 2013; 2nd ed. 2016). 
Plato and Aristotle and by the Church Fathers, especially St. Augustine, Bishop of Hippo. This will occupy us in the subsequent section. Undoubtedly, any thorough examination of the meaning of happiness entails many deeply theological and philosophical reflections. Happiness is both a material and a spiritual condition, as has been discussed already since antiquity and beyond. The specific definition of happiness has commonly focused not so much on an emotional component, but on the question what constitutes a good life, whether we think of ethical, moral, religious, but then also economic, political, and social criteria. As Aristotle already taught us in his famous Nicomachean Ethics, only a cluster of criteria, if fulfilled or materialized, would allow us to determine happiness in human life, what he called eudaimonia. These pertain to virtues, material goods, the long duration of a satisfactory and meaningful life, and a good death.

Aristotle was very clear about the need for people to enjoy material goods since those serve as auxiliary means making the realization of virtues and other abstract values possible in the first place. A good balance, in other words, supports, according to his teachings, the endeavor to lead a good life and hence to enjoy happiness. ${ }^{19}$ For the present purpose, I cannot do justice to his teachings at large, since that would lead us entirely into the field of ancient philosophy..$^{20}$ By contrast, the purpose next consists of outlining how

19. These and similar aspects have already been discussed from many different perspectives; see, for instance, Günther Bien, "Ethik, II: Griechisch-römische Antike," in Theologische Realenzyklopadie, ed. Gerhard Krause and Gerhard Müller. Vol. X (Berlin and New York: Walter de Gruyter, 1982); Jon Miller, The Reception of Aristotle's Ethics (Cambridge: Cambridge University Press, 2012). For a very useful survey, summary, and discussion of Aristotle's Nicomachean Ethics, see https://en.wikipedia. org/wiki/Nicomachean_Ethics, accessed January 8, 2017; cf. also Christopher Warne, Aristotle's Nicomachean Ethics: Reader's Guide (London: Continuum, 2007).

20. For useful, though very brief biographical sketches, see, for instance, Gillian Rosemary Evans, Fifty Key Medieval Thinkers (London and New York: Routledge, 2002). The critical literature on these great philosophers and theologians is simply legion, and yet their teachings deserve to be revisited and re-examined especially in our context. See also Severin Kitanov, Beatific Enjoyment in Medieval Scholastic Debates: The Complex Legacy of Saint Augustine and Peter Lombard (Lanham, MD: Lexington Books, 2014). We also would have to consider the history of stoicism from antiquity to the modern world, which added important concepts to the pursuit of happiness as well. See Steven K. Strange and Jack Zupko, ed., Stoicism: Traditions and Transformations (Cambridge and New York: Cambridge University Press, 2004). Moreover, to do full justice to the topic at hand, we would have to consult many medieval philosophers and theologians, such as Thomas Aquinas; see, for instance, Denis J. M. Bradley, Aquinas on the Twofold Human Good: Reason and Human Happiness in Aquinas's Moral Science (Washington, DC: Catholic University of America Press, 1997); or Albertanus of Brescia; cf. James M. Powell, Albertanus of Brescia: The Pursuit of Happiness in the Early Thirteenth Century (Philadelphia: University of Pennsylvania Press, 1992). For 
three very different voices from the past can help us understand much more about our own existence than we might have thought so far. The central claim hence consists, in order to formulate it once again, that we need to maintain a close connection to the pre-modern world in order to grasp the present, and thus also the future.

Both the Church Father Saint Augustine, Bishop of Hippo (345-430), and Boethius (d. 525), the great philosopher and teacher from the early sixth century, already provided powerful messages about happiness that deserve to be kept alive because they prove to be universal, highly penetrating, insightful, and, above all, meaningful both for their contemporaries and for us today. While most medievalist scholars would accept this perspective without any hesitation, here I want to pursue the question to what extent their insights allow us to acknowledge until today that their statements continue to matter for us most powerfully and that consequently we can and should open our minds toward the pre-modern world for the exploration of the meaning of all human existence. If, then, both of these two thinkers, and some other medieval writers might have some significance in the eternal search for meaning, then we would be in the ideal position of recapturing the Middle Ages as crucial within the wide field of the Humanities.

\section{Augustine, Bishop of Hippo}

In his Happy Life from 387, Augustine discusses with a group of his friends how to achieve inner, spiritual truth, which promises to yield insight into the way how to establish spiritual happiness. ${ }^{21}$ This provides a profound basis for our own investigation what true happiness might mean, both then and today.

For Augustine, there are three types of people who venture out to sea in this life and probe how they can find their way through human existence in a metaphorical manner. They all pursue the similar goal of reaching the world

broader perspectives, see Sabine Meck, Vom guten Leben: eine Geschichte des Glücks (Of Good Life: A History of Good Fortune) (Darmstadt: Wissenschaftliche Buchgesellschaft, 2012).

21. Augustine of Hippo, Selected Writings, trans. and intro. Mary T. Clark (New York, Ramsey, and Toronto: Paulist Press, 1984). See now also Aurelius Augustinus, De beata vita: lateinisch/deutsch = Über das Glück (On the Good Life: Latin/German $=$ On Good Fortune) trans., remarks and afterword Ingeborg Schwarz-Kirchenbauer and Willi Schwarz (Stuttgart: Philipp Reclam, 1989); Richard Avramenko, "The Wound and Salve of Time: Augustine's Politics of Human Happiness," The Review of Metaphysics 60, no. 4 (Jun., 2007), outlines the major changes which Augustine pursued in his later City of Good (9.14) where he then claimed that in this material existence no true happiness will ever be possible. 
of happiness, but each one faces different challenges. Without going into details, Augustine highlights the difficulties which the sea warrior faces both in the open ocean and even in the harbor, all representatives of life which the individual is pursuing in his course throughout existence. In his discussion he reaches, first of all, the insight that we consist of a body and a soul, hence of material and spirituality. If the soul is denied nutrition, it would begin to suffer. Differentiating between things that we want but do not need and things that we want and do need, Augustine highlights how the soul is truly fed with good things. Receiving what one wants and needs at the same time, and gaining it not just at the spur of the moment, but for ever, would be the basis of happiness (175). Happiness, hence, depends on endurance, far away from being ephemeral.

Those who rely on physical objects to gain happiness would have to realize that they depend on chance since they can lose everything at any time. Fear thus proves to be an essential component of material things since they can get lost. "Therefore, whoever loves and possesses such things can in no way be happy" (176). In the exchange with his mother, he then concludes that the material elements by themselves do not provide happiness, whereas eternal, spiritual elements do so. Ultimately, then, happiness only rests in God.

Turning to the academics, Augustine describes them as seekers of truth, which remains, however, intractable and elusive, and so he determines them as constantly unhappy because they do not pursue God (178). Happiness, thus, rests in God, and people can achieve happiness if they have a clean and pure spirit and aspire for God (181-82). In their discussion, Augustine reaches the preliminary conclusion: "whoever seeks God has God favorably inclined toward him, and everyone who has God favorably inclined toward him is happy; hence, he who is seeking is happy; but he who seeks does not yet possess what he wants; consequently, he who does not have what he wants will be happy" (183). In other words, for him the quest itself constitutes a crucial component of happiness itself. There would not be a guarantee on happiness just because one would be seeking for God's favor, but the search itself represents a most critical feature essential for achieving happiness.

Those who are needy and do not receive what they really want are identified as unhappy. By contrast, "whoever is without needs is happy" (185). However, Augustine is not so blind or so idealistic to urge us to overcome all bodily and material needs, since we are human beings who must ingest and digest in order to live: "even wise men need certain things for their bodies" (185). Nevertheless, the body should not rule the soul, since all physical provisions could run out and bring about death for the body. But the body ought not to be the primary purpose of our life because death and pain are not completely unavoidable. In order to achieve happiness, then, the individual ought to embrace this situation and reduce the needs and only "wish for what is possible" (186). The richest people, sensitized to their own situation, would 
be terror-stricken by the fear that someone could steal it from him or destroy his wealth. But only wise individuals are capable of grasping the difference between false and true happiness and thus regularly become victims of their self-delusion, pursuing the wrong goal where never full and ever-lasting happiness can be achieved (187).

In short then, for Augustine, being in need of something in material terms represents a form of foolishness, the very opposite of wisdom, and hence also the lack of happiness. In his own words: "just as all need is to be considered unhappiness, so all unhappiness is to be considered need" (188). Happiness and wisdom thus prove to be basically one and the same, just as need, foolishness (stultitia), and unhappiness also prove to be synonyms. Little wonder that almost thousand years later the German Humanist Sebastian Brant entitled his famous satirical work Ship of Fools (1494; Narrenschiff, or Stultifera navis). Augustine does not argue from a theological point of view; instead he pursues a philosophical logic, emphasizing that foolishness constitutes unhappiness insofar as being in need represents the former, foolishness.

Those who are unhappy hence have to be identified and characterized as foolish since they do not understand how to differentiate between what one needs and what one does not need. In order to gain happiness hence would not be a process of gaining material wealth or to overcome need by acquiring objects, but to establish wisdom and to leave behind need where there should not be any. Augustine, in other words, suggests to approach the task at hand not through a religious, moral, or ethical perspective, but by way of a philosophical strategy addressing the primary question of what humans really need, and not what they want. Almost in a Buddhist or Socratic fashion, he emphasizes over and over again that only the true absence of need would ultimately produce true happiness. As he emphasizes in his own words: "to be happy is nothing but not to be in need, that is, to be wise. As examples of false concepts of happiness, he mentions luxuries, tyrannies, prideful performance in public, that is, all such things that make the individual restless, worrisome, fearful, preoccupied, and sorrowful."

Although it might be difficult to determine whether the Middle High German poet Rudolf von Ems (fl. ca. 1215-ca. 1250) was an Augustinian and hence influenced by the teachings about the true happy life, we might cite his Der guote Gêrhart (The Good Gerhart, ca. 1220) as an example of how Augustine' s thoughts became applied in the medieval literary discourse. The entire romance is focused on the question how one can achieve goodness here on earth and whether one then should expect a reward already during one' s lifetime. While the Emperor Otto falls into the trap of this kind of thinking, praying to God to let him know already now what reward he could expect in the afterlife for his establishment of a bishopric in Magdeburg, the Cologne merchant Gerhart presents the very different approach. As he tells the 
emperor upon his insistent urging, he had performed many good deeds but never asked for any reward, and even rejected all offers to repay him for his enormous generosity. Looking for praise here on earth would destroy the quest for the soul's salvation in the afterlife..$^{22}$ In other words, the protagonist has repressed all of his needs for worldly honor/praise and has thus become free of any needs, which truly makes him happy, as he emphasizes throughout the text. This is a signal concept which later thinkers will pick up and develop further, urging us to keep in mind the central need to overcome human contingency and thus to reach the realm of liberty, hence happiness. ${ }^{23}$

As Augustine highlights then, the individual searching for true happiness must put aside all vanity, free himself from deceptions regarding false gods, and remove all fear about one's existence, so as to allow the full freedom from needs come to fruition: "Whoever therefore has his own measure, that is, wisdom, is happy" (192). Of course, at that point Augustine breaks off his discussion of those philosophical considerations and turns to the theological dimension, concluding that only those would fully experience happiness who would accept and embrace God. Taking the next step, he then underscores that truth constitutes the highest degree of measure, and that for souls "this is to possess God, that is, to enjoy God" (192). In God there is perfection, as Augustine preaches, and hence ultimate happiness, but in this final section of his treatise he argues no longer philosophically, but theologically: "This, therefore, is the complete satisfaction of souls, that is, the happy life: to know precisely and perfectly Him through whom you are led into the truth, the nature of the truth you enjoy, and the bond that connects yo with the Supreme Measure!" (193).. ${ }^{24}$ Even though Augustine was later, in his

22. Rudolf von Ems, Der guote Gêrhart, ed. John A. Asher (Tübingen: Max Niemeyer, 1962). See now my English translation of that text (Albrecht Classen, An English Translation of Rudolf von Ems's Der guote Gêrhart (Newcastle upon Tyne: Cambridge Scholars Press, 2016)), which includes an extensive introduction and a comprehensive bibliography. For a solid discussion of this text, see, for example, Sonja Zöller, Kaiser, Kaufmann und die Macht des Geldes: Gerhard Unmaze von Köln als Finanzier der Reichspolitik und der "Gute Gerhard" des Rudolf von Ems (Emperor, Merchant, and the Power of Money: Gerhard Unmaze of Cologne as Financial Sponsor of Imperial Politics and Rudolf von Ems's “Gute Gerhard") (Munich: Wilhelm Fink Verlag, 1993). In my introduction to the translation, I discuss both the history of research and the historical framework, including surprising connections to the works of the eleventh-century Rabbi Nissim, one of whose texts appears to have deeply influenced Rudolf, apart from Augustine's teachings.

23. Hartmut Böhme, Werner Röcke, and Ulrike C. A. Stephan, ed., Contingentia: Transformationen des Zufalls (Contingency: Transformations of Happenstance) (Berlin and Boston: Walter de Gruyter, 2015).

24. For further discussions of this central topic, see Patricio Domínguez, Augustins Philosophiebegriff: Fides und Ratio im Hinblick auf die Glücksfrage (St. 
Retractions (1.2), to redefine particularly the concept that it would be possible to achieve happiness already here in this world, insisting that true happiness can only to be had through the soul with God, the entire dialogue treatise composed in 386 at Cassiciacum near Milan laid the foundation for subsequent investigations of this fundamental question. Insofar as Augustine became one of the most influential writers for the entire Middle Ages, and well beyond until today, ${ }^{25}$ we can extract some of the critical components relevant in all philosophical and theological discourses pertaining to happiness from that monumental writer.

\section{Boethius}

The other voice that deserves to be mentioned here is that by Boethius who in 525, shortly before his execution by stoning for alleged but certainly trumped up charges of state treason, composed his famous treatise $D e$ consolatione philosophiae (Consolation of Philosophy). ${ }^{26}$ His huge impact on the intellectuals and writers from the subsequent centuries does not need to be reviewed here once again, but we need to keep in mind the purpose of our renewed discussion of his teachings. Boethius's reflections confirm once again, especially in light of his enormous influence, how much ancient voices deserve greatest respect today since they apparently had formulated already universal truths that have not changed until today. Of course, Boethius's dialogue between himself and philosophy does not constitute literature in the narrow sense of the word, irrespective of the numerous poetic renderings of the prose reflections. Nevertheless, it would be difficult to identify any medieval writer who would not have been familiar with his teachings in one

Augustine's Concept of Philosophy: Faith and Rationality Regarding the Question About Happiness) (Paderborn: Ferdinand Schöningh, 2016). See also Michael Klaus Wernicke, Glücklich wollen wir mit Sicherheit sein: Augustinus' Suchen nach dem Glauben (We Want to be Happy, for Sure: Augustine's Search for Faith) (Würzburg: Echter, 2015).

25. Karla Pollmann and Willemien Otten, ed., The Oxford Guide to the Historical Reception of Augustine (Oxford: Oxford University Press, 2013).

26. Boethius, Consolation of Philosophy, trans., intro. and notes Joel C. Relihan (Indianapolis, IN, and Cambridge: Hackett Publishing, 2001); Classen, "What do they mean for us today?"; Classen, "Boethius' 'De consolatione philosophiae'. Eine 'explication du texte' ('Boethius' 'Of the consolation of philosophy'. An 'analysis of the text')," Jahrbuch für internationale Germanistik XXXII no. 2 (2000); Thomas Böhm, Thomas Jürgasch, and Andreas Kirchner, ed., Boethius as a Paradigm of Late Ancient Thought (Berlin and Boston: Walter de Gruyter, 2014). For the history of reception concerning this late antique philosopher, see Noel Harold Kaylor, Jr., and Philip Edward Phillips, ed., A Companion to Boethius in the Middle Ages (Leiden and Boston: Brill, 2012). 
way or the other. ${ }^{27}$ Both from a theoretical (instructional) and a practical perspective, this dialogue treatise has proven many times to be of timeless value because it teaches truly fundamental lessons. For the present purpose I can only touch upon the key points and connect those with the remarks by Augustine.

Taking his own concrete situation as his starting point, Boethius bitterly complains to the allegorical figure Philosophy about the injustice done to him, being imprisoned and awaiting his execution, though he is innocent. He argues vehemently that he is suffering from unfair treatment and insists that this maltreatment should have never occurred to him. In their long conversations, however, Philosophy slowly teaches him first to understand the true nature of Fortune, a universal instrument operating here in this world, determining the life of every creature, sometimes granting good fortune, sometimes taking it away again. The only consistency of Fortune is its very inconsistency, so the prisoner Boethius has to learn quickly that all the traditional criteria normally quoted as powerful in granting happiness are thoroughly rebuffed and exposed as temporary, unstable, untrustworthy, and particularly deceptive. Philosophy also points out that Boethius does not really have a reason to complain about his misery because throughout his entire life he has enjoyed many good things and should be rather thankful than downtrodden. Good fortune, however defined, belongs to Fortune, and not to the individual: "If the things whose loss you complain of had ever been yours, there would have been no way you could have lost them" (25). In fact, Philosophy formulates the question how he could have forgotten the long series of happy moments in his life, and why he would now lament about one small misfortune that is taking his life (28-29). She does not ridicule him with this commentary, even if it might sound like that, but she is completely correct in putting everything into the proper relationship, allowing Boethius to perceive his existence within the larger schema of things. Most significantly, we learn that no one here on earth who might be looking for happiness by way of pursuing material goods, or power, etc, will ever achieve the goal: "no one is in simple harmony with the condition of his own Fortune, for in every single Fortune there is something present that the outsider has no knowledge of, but that the insider shrinks from in horror" (31).

While Augustine had emphasized freeing oneself from "need" in order to experience happiness, Boethius relies on the term and concept of "detachment," because true happiness does not rest in temporary, material objects, which are all subject to Fortune. The very nature of Fortune, however, proves to be its changeability and instability. Most egregiously, once death has arrived, the individual can no longer rely on his/her body, the source of much joy, but

27. John Marenbon, ed., The Cambridge Companion to Boethius (Cambridge and New York: Cambridge University Press, 2009). 
also much misery. In other words, happiness must be sought beyond Fortune and its workings, which create nothing but illusions and deceptions. Worldly glory thus emerges as one of the most dangerous traps because those who achieve fame or even seek out fame pursue a path entirely determined by Fortune. Most beautifully, Philosophy then alerts Boethius to the great advantage of misfortune because that would be the only catalyst or litmus test to determine what the true good would be, and hence also who the true friends are: "Go on, complain about the wealth and resources that you have lost; you have found what is the most valuable kind of riches, your friends" (46). The ultimate goal, however, still continues to be to achieve happiness, which none of those fortune-driven aspects can secure. These are all contingency based and unreliable, fleeting, and evanescent, hence deceiving and illusionary. True happiness, according to the teachings of Philosophy, really rests somewhere else.

While Augustine had basically broken off at that point in his arguments and then had quickly switched to God as the final source of happiness, Boethius has Philosophy turn to a higher level of intellectual ruminations, once having worked through the analysis of the very nature of Fortune. Just like Augustine, Philosophy emphasizes that need, or contingency, misleads us in our quest for happiness, where freedom of that contingency would be the gateway toward the true goal of all existence.

Self-sufficiency emerges as an equivalence to power, and that in turn as an equivalence to preeminence, which reveals itself as the basis of happiness. Of course, no one here on earth can simply pursue that path, but once Fortune has been dismissed as an unreliable instrument in all our efforts to gain true happiness, the strife toward self-sufficiency, which Philosophy also identifies as goodness and then even further as oneness, represents the true key toward that goal. By the same token, there is no chance for people ever to be entirely selfreliant, to be free of any outside help, and self-contained completely, except for God, or the supreme good, as he rather calls it in his philosophical discourse (68) God is, as Boethius calls it, the very essence of happiness and goodness, oneness and self-sufficiency, all terms for one and the same phenomenon. However, while there is a huge gulf between this summum bonum and us as human beings, everyone can aspire for joining that entity which entails fullest delight. On the premise that the origin of all being was perfection, everything present today is the manifestation of the evolution away from that perfect goodness in material terms. Yet, as much as people seem far removed from that final stage, that is, complete happiness, as much can they try to join God/ goodness and become part of Him, and thus share in His happiness. Even if that will most likely not be possible here in this life, the individual is called upon to struggle with all his/her might to get closest to that ideal (75-76) and to become part of God. Since all people aim for happiness, the ultimate goal of all existence, they can only realize their ideal by leaving Fortune behind and 
joining with God, driven by the desire for oneness (79).

This then leads Boethius to have Philosophy explain in a stunning manner one of the principle concepts underlying his entire teaching, turning to natural objects, such as grass, flowers, and trees, to animals and fish, and even to stones and rocks as metaphors of the universal law determining all beings. Everything that is part of life wants to live and thus tries its hardest to live well and to the best of its potentials. There is, as Philosophy underscores, a "natural striving" (81), which determines all existence, toward the selffulfillment, and away from destruction and self-hurt. She explains further: "Consequently, there is no reason why you could in any way doubt that all the things that exist crave by their nature the permanence of remaining unchanged and by their nature avoid dissolution" (82). Being is thus defined as the desire for the good, or happiness: "Good is the goal of all things" (83).

Perhaps surprisingly, but certainly logically, Philosophy then reaches the next insight that all beings are naturally driven by the desire to be good, to be part of good, and to enjoy all the good, which would be nothing but another expression for happiness (86). Living beings can thus not even stay away from this attraction by and toward the good and have to follow their natural "instinct" in that process. In essence, then, life is determined by the desire to achieve the good and hence to gain happiness.

A startling corollary results from this observation. As Philosophy elucidates, if by nature all living things aim for the good and cannot really stray from the straight path toward that goal, then the phenomenon of "evil" does not really exist (87), or at least has to be viewed with greatest pity because those who are evil in human terms prove to be the weakest individuals here on earth, not able to follow their own instinct and instead striving against the natural desire for goodness and happiness. If the principle of life consists, as it has been determined so far, of achieving goodness, it is selfevident that those who aim for it are all powerful and self, while the evil ones display the greatest weakness and fail to achieve even the slightest because they struggle against their own instinct and their own inner desires: "the good are powerful, while those who are evil are incapable" (95). In fact, Philosophy even claims that they do not really exist because they have already eliminated themselves through their contrariness directed against their own nature, filled with the instinct taking them toward the good: "wicked deeds do not come into the realm of true happiness" (99).

We might hence conclude with one more quote from Boethius: "it is in this way that whatever falls away from the Good ceases to exist. And so it happens that evil people cease to be what they once were" (101). They deserve to be pitied and have to be regarded as miserable, deplorable being who are the weakest of all creatures, even though they cause much pain and suffering for the good ones (108-09).

From here Boethius wanders into other directions, probes the meaning of 
punishment of the evil, and then investigates the relationship between free will and providence. The philosophical, moral, and religious aspects then grow in weight in the overall schema of this treatise, but throughout the subsequent centuries when Boethius experienced ever more popularity and exerted a deep influence on the entire Middle Ages and well beyond, the earlier aspects of his teaching dominated. The true nature of Fortune, its deceptiveness, and the illusion associated with false concepts of happiness were discussed and examined in many different forms, texts, genres, contexts, and versions throughout the following periods. ${ }^{28}$ The image of the wheel of fortune found entrance into many different literary and philosophical texts (e.g., Shakespeare), and the fundamental treatment of goodness as the notion of inner freedom from contingency shaped much of western critical thinking. ${ }^{29}$

Would it be wise today to dismiss Boethius's Consolation of Philosophy from our canonical reading lists? Has the puzzlement about the dominance of evil people ever abated, and hence the question why the good ones do not seem to make headway and tend to suffer at the hands of the former? Hardly, and yet it is shocking to notice that less and less of the current student population, for instance, knows anything about Boethius and his profound insights. But I leave this polemic aside and simply highlight one final time how much his critical reflection on the essence of human existence penetratingly cuts through many misconceptions and clarifies in a rather stunningly logical manner, without relying on religious perspectives, the true meaning of fortune, misfortune, happiness, and the illusionary function of evilness.

28. Albrecht Classen, "Gutes Leben und guter Tod von der Spätantike bis zur Gegenwart: Ein philosophisch-ethischer Diskurs über die Jahrhunderte hinweg" (Good Life and Good Death from Late Antiquity to the Present: A PhilosophicalEthical Discourse Across the Centuries), in Gutes Leben und guter Tod von der Spätantike bis zur Gegenwart: Ein philosophisch-ethischer Diskurs über die Jahrhunderte hinweg (Good life and good death from late antiquity to the present: a philosophical-ethical discourse over the centuries), ed. Albrecht Classen (Berlin and New York: Walter de Gruyter, 2012).

29. Classen, "What do they mean for us today?"; Noel Harold Kaylor, "The English and German Translation Traditions of Boethius's De consolatione philosophiae," Studia Litteraria Universitatis Iagellonicae Cracoviensis 10, no. 1 (2015). 


\section{Gautier de Coincy}

From here we could turn to a plethora of further texts where timeless messages about our human life find pointed expressions. But then we would face the same old danger once again of not seeing the forest for all the trees. Consequently, to round off our discussion of the meaning and importance of pre-modern voices, I close with a short examination of the profound, but once again mostly ignored and unknown religious tale of "The Tumbler" by Gautier de Coincy (1177-1236), who was a French abbot, poet and musical arranger who gained his greatest fame for his deep admiration of the Virgin Mary expressed in literary terms. Most famous are his "Les Miracles de NostreDame (known in English as The Miracles of Notre Dame or The Miracles of Our $L a d y$ ) in which he set poems in praise of the Virgin Mary to popular melodies and songs of his day. It is a reverential but humorous work, full of love for the cult of the Virgin Mary, which at that time also received attention from Saint Bernard of Clairvaux who was the leading medieval proponent of veneration of the Virgin as a counterbalance to the more rigorous Christian scholasticism, then the dominating spiritual force." ${ }^{30}$

In the account of "The Tumbler," a simple-minded man joins a Cistercian monastery because he wants to worship the Virgin Mary with all of his heart. Unfortunately, he quickly realizes that he does not have the intellectual competence to participate in the usual monastic rituals and duties, as much as he might try. In his desperation he removes himself from the church services and hides in the crypt where he faces the Virgin all by himself. Instead of praying to her, or reading in a breviary or psalter, he then decides to resort to the only thing that he really knows how to do and to do well, that is, he begins to tumble, which was his original profession before joining the monastic community.

He quickly realizes that this approach truly helps him to achieve his goal because he can dedicate his entire being to this unique form of service to her. While the other monks perform hymns for the Virgin, he diverts her, as he realizes, in the hope to achieve her grace thereby (106). As the narrator then

30. Lauri Lindgren, Les miracles de Notre Dame de Soissons versifiés: Versifiés par Gautier de Coinci (The Miracles of Our Lady of Soissons: Versified by Gautier de Coinci) (Helsinki: Finnish Academy of Science, Series B, 1963). Here I draw from the English translation in Medieval Answers to Modern Problems (Classen, 105-110). See also the useful, in fact excellent survey article online at: https://en.wikipedia.org/wiki/Gau tier_de_Coincy (accessed January 8, 2017), which proves to be superior to much what has written about Gautier in the past. Many dictionaries and encyclopedias dedicated to the Middle Ages either ignore this poet altogether, or mention him only in passing. But see, at least, Maureen B. M. Bolton, "Gautier de Coincy," in Medieval France: An Encyclopedia, ed. William W. Kibler and Grover A. Zinn (New York and London: Garland Publishing, 1995), 386. 
comments: "so greatly did it please him, and with such right good will did he do this, that never a day was he so tired that he could not do his very utmost to delight the Mother of God, and never did he desire to do other service" (107).

While he happily pursues this strategy in the firm belief to do good and thus to reach out to the Virgin Mary, another monk notices his regular absences, follows him, observes his curious behavior, and reports all this to the abbot. However, he does not express anger or jealousy; on the contrary, he expresses great amazement and even joy: "We pray for him, and he plays for us! If we weep, he soothes us! I would that all the convent could see him at this very moment just as I do, even if I had to fast for it till dusk!" (107). Joy and laughter would result if the others could witness the happy scene in the crypt where the tumbler demonstrates true devotion in a most joyful manner: "God counts it unto him for penance, for he does it without evil intent, and, certes, I hold it not to be ill, for, as I believe, he does it, according to his lights, in good faith, for he wishes not to be idle" (107).

Amazingly, when next the abbot and the monk re-enter the crypt to observe the tumbler, they are suddenly privy to a miracle which transforms them as well and provides them with a supreme example of true happiness. After having tumbled for a long time, the simple man collapses to the ground out of exhaustion, but at that very moment, as the spies clearly notice, a vision appears, with the Virgin Mary, accompanied by a host of angels, approaching the tumbler and comforting him: "And the sweet and noble Queen took a white cloth, and with it she very gently fanned her minstrel before the altar" (108). Even though the tumbler does not perceive any of that himself, for the abbot it is immediately clear that this tumbler has achieved the status of a saint, calling him a "holy man" (108).

When the abbot later calls the tumbler into his office and queries him about his actual contributions to the community, the latter deeply fears that he might have been found out as a failure and would be relegated from the monastery. However, the complete opposite happens since the abbot acknowledges him as a saintly person, begging him to "pray for me and I will pray in return for you" (109). In fact, the abbot enjoins him to continue with his service to the Virgin Mary, but from now on publicly since it proves to be the most worthy performance driven by a sincere heart. ${ }^{31}$ Unfortunately, the tumbler soon after falls sick and then dies, but he is worshiped by everyone in the monastery as a truly holy person.

As the narrator concludes, "Cheerfully did he tumble, and cheerfully did he serve, for the which he merited great honour, and none was there to

31. It was not that unusual for the medieval Church to include artistic performances as part of their religious services; see Philip Knäble, Eine tanzende Kirche: Initiation, Ritual und Liturgie im spätmittelalterlichen Frankreich (A dancing church: initiation, ritual and liturgy in late medieval France) (Cologne, Weimar, and Vienna: Böhlau, 2016). 
compare unto him" (110). In short, the tumbler had achieved true happiness because he had dedicated himself entirely to the service of the Virgin Mary, dedicating to her everything he had, which was only little, and yet much more than what all the other monks could do since his heart was most profoundly driven to carry out this performance. With his tumbling on her behalf he gave all he had, and thus achieved the highest honor in a spiritual sense. But at the same time, as Gautier also indicates, the tumbler secured true happiness for himself insofar as he achieved the goal his entire being strove for; but not in material or political terms; instead, all of his desires were aimed at the Virgin Mary, and even though he himself did not witness her, the abbot and the monk observed the vision and could thus recognize the sanctity of this simple man.

The narrative might be a rather plain religious story, but it entails amazing insights into the true quest for happiness. Even though the tumbler did not command the basics of a religious life in a monastery, his mind-set was truly pious and committed to serve the Virgin Mary. He could not follow the standard procedures, rituals, and ceremonies, not being smart enough for anything apart from his physical exercise. Yet, once he had realized that there was a particular avenue for himself to pursue his own agenda, his own goal in life, he set his whole heart to that and actually achieved more than all the learned monks, including the abbot. As Gautier thus implies, for the achievement of true honor, happiness, and sanctity it would not matter whether the individual knows how to meet the formal, official expectations, but whether $\mathrm{s} /$ he understands the inner demands and embraces them full-heartedly. The tumbler gained full respect not because of his tumbling, which was actually ridiculous for a monk, but for his passion, devotion, commitment, and firm belief. He understood that he could not give to the Virgin Mary what the other monks gave, through prayer, reading the mass, confession, singing hymns, studying the Bible, etc. But he could give what he knew best, and he committed himself completely to this service, for which he ultimately gained divine grace and could die as a holy man.

\section{Conclusion}

While the treatises by St. Augustine and Boethius outlined the theoretical underpinnings of how to achieve happiness, the religious tale by Gautier conveyed the message in pragmatic terms how to behave, what to do in life in order to transcend the material, political confinements of human life and to reach a higher level in human existence. As odd as "The Tumbler" might seem at first sight, especially for readers in the twenty-first century, a modest translation of the medieval and religious components into contemporary terms easily makes possible to grasp the universal and timeless message 
contained here. Give it all, be it all, commit to it all.

There are, of course, huge differences between the two treatises from late antiquity and this thirteenth-century religious narrative. Nevertheless, they all share the same interest in and concern with the ultimate question of how a human being can grow and gain insights into the finite conditions of true existence beyond the limits of fortune. While Augustine aimed specifically for God, and while Boethius elaborated the learning process that should take the individual outside of the prison created by fortune and to aim for the ultimate goodness, which is naturally engraved in the human nature, Gautier presented a practical example how to experience full happiness.

All three writers presented deeply insightful, illuminating, and farreaching teachings regarding the conditions of human life. The contemporary reader cannot simply expect to find a direct connection to those lessons, and yet there are multiple possibilities to draw from Augustine, Boethius, and Gautier for the living conditions today. Naturally, we are all called upon to move forward, to engage with society, to work on our own ideals and dreams, and hence to build the foundations for the future. But as our analysis has clearly demonstrated, this process can be much facilitated if we also keep past experiences in mind, listen to voices from the pre-modern world, and acknowledge them as important contributors to the on-going discourse regarding human happiness and hence regarding the ultimate meaning of life.

We probably could not survive, of course, if we relied exclusively on the cultural, philosophical, literary, and religious tradition from the previous centuries and millennia, but we would also badly deprive ourselves if we closed our eyes to the past and ignored the deepest insights developed already then most powerfully. The ideas expressed by Augustine, Boethius, and then Gautier, apart from those formulated by many other contemporaries, carry on until today and demonstrate their great validity. This grants us a new and very old perspective toward the Humanities, since those ancient and medieval voices empower us even now to grasp the conditions of all life and the avenues how to reach our future. After all, the essential ethics, morals, and ideals shared by most people throughout time do not change; whereas the historical circumstances and conditions do so continuously.

\section{Bibliography}

Augustine of Hippo. Selected Writings. Translation and Introduction by Mary T. Clark, 163-193. New York, Ramsey, and Toronto: Paulist Press, 1984. Augustinus, Aurelius. De beata vita: lateinisch/deutsch = Über das Glück (On the Good Life: Latin/German = On Good Fortune). Translation, Remarks, and Afterword by Ingeborg Schwarz-Kirchenbauer and Willi Schwarz. Stuttgart: 
Philipp Reclam, 1989.

Avramenko, Richard. "The Wound and Salve of Time: Augustine's Politics of Human Happiness." The Review of Metaphysics 60, no. 4 (Jun., 2007): 779-811.

Bartolini, Stefano, Bilancini, Ennio, Bruni, Luigino, and Porta, Pier Luigi. Policies for Happiness. Oxford: Oxford University Press, 2016.

Bien, Günther. "Ethik, II: Griechisch-römische Antike." In Theologische Realenzyklopadie, edited by Gerhard Krause and Gerhard Müller. Vol. X, 408-423. Berlin and New York: Walter de Gruyter, 1982.

Boethius. Consolation of Philosophy. Translation, Introduction and Notes by Joel

C. Relihan. Indianapolis, IN, and Cambridge: Hackett Publishing, 2001.

Böhm, Thomas, Jürgasch, Thomas, and Kirchner, Andreas, ed. Boethius as a Paradigm of Late Ancient Thought. Berlin and Boston: Walter de Gruyter, 2014.

Böhme, Hartmut, Röcke, Werner, and Stephan, Ulrike C. A., ed. Contingentia: Transformationen des Zufalls (Contingency: Transformations of Happenstance). Berlin and Boston: Walter de Gruyter, 2015.

Bolton, Maureen B. M. "Gautier de Coincy." In Medieval France: An Encyclopedia, edited by William W. Kibler and Grover A. Zinn. New York and London: Garland Publishing, 1995.

Boniwell, Ilona, David, Susan A., and Ayers, Amanda Conley, ed. The Oxford Handbook of Happiness. Oxford: Oxford University Press, 2013. DOI: 10.1093/ oxfordhb/ 9780199557257.001 .0001$.

Bradley, Denis J. M. Aquinas on the Twofold Human Good: Reason and Human Happiness in Aquinas's Moral Science. Washington, DC: Catholic University of America Press, 1997.

Center, Katherine. Happiness for Beginners. New York: St. Martin's Griffin, 2015.

Classen, Albrecht. "'Boethius' 'De consolatione philosophiae'. Eine 'explication du texte'." ('Boethius' 'Of the consolation of philosophy'. An 'analysis of the text'). Jahrbuch für internationale Germanistik XXXII no. 2 (2000): 44-61.

Classen, Albrecht. "Gutes Leben und guter Tod von der Spätantike bis zur Gegenwart: Ein philosophisch-ethischer Diskurs über die Jahrhunderte hinweg" (Good Life and Good Death from Late Antiquity to the Present: A Philosophical-Ethical Discourse Across the Centuries). In Gutes Leben und guter Tod von der Spätantike bis zur Gegenwart: Ein philosophischethischer Diskurs über die Jahrhunderte hinweg (Good life and good death from late antiquity to the present: a philosophical-ethical discourse over the centuries), edited by Albrecht Classen, 1-109. Berlin and New York: De Gruyter, 2012.

Classen, Albrecht, ed. Medieval Answers to Modern Problems. San Diego: Cognella Inc. \& University Readers, 2012; rev. ed. 2013; 2nd ed. 2016.

Classen, Albrecht. "What do they mean for us today? Medieval Literature and Philosophy at the End of the Twentieth Century. Boethius, John of Salisbury, Abelard, and Christine de Pizan." Mediaevistik 12 (1999): 185-208.

Classen, Albrecht. "Medieval Studies within German Studies: The Nibelungenlied and Hartmann von Aue's Der arme Heinrich)." In Taking Stock of German 
Studies in the United States: The New Millennium, edited by Rachel Halverston and Carol Anne Costabile Heming, 52-67. Rochester, NY: Camden House, 2015.

Classen, Albrecht. "Friendship, Death, and Boethian Philosophy in the High Middle Ages: The Meaning of the Past for Our Present and Future. With a Special Focus on Lawrence of Durham's Consolatio (1141) and Aelred of Rievaulx's De Spirituali Amicitia (1164-1167)." Medieval Perspectives 28 (2013): 9-31.

Classen, Albrecht. "The Literary Treatment of the Ineffable: Mechthild von Magdeburg, Margaret Ebner, Agnes Blannbekin." Studies in Spirituality 8 (1998): 162-187.

Classen, Albrecht. "Worldly Love - Spiritual Love. The Dialectics of Courtly Love in the Middle Ages." Studies in Spirituality 11 (2001): 166-186.

Classen, Albrecht. "The Dialectics of Mystical Love in the Middle Ages: Violence/Pain and Divine Love in the Mystical Visions of Mechthild of Magdeburg and Marguerite Porète." Studies in Spirituality 20 (2010): 143-160.

Classen, Albrecht. "Mystical Visions and Spiritual Health: Medieval Mysticism As A Platform for the Exploration of Human Spirituality and Happiness: The Transcendence of the Body in the Quest for the Godhead - A Message for Us Today?." Studies in Spirituality 25 (2015): 117-138.

Classen, Albrecht. "The Meaning of Literature - A Challenge of Modern Times - What the Sciences Cannot Teach Us. With Emphasis on the Gesta Romanorum, Boccaccio's Decameron, Lessing's Nathan the Wise, and the Verse Narratives by Heinrich Kaufringer." Humanities 5, no. 24 (2016). Accessed January 8, 2017. DOI:10.3390/h5020024.

Classen, Albrecht. An English Translation of Rudolf von Ems's Der guote Gêrhart. Newcastle upon Tyne: Cambridge Scholars Press, 2016.

Classen, Albrecht. "The Quest for Knowledge Within Medieval Literary Discourse: The Metaphysical and Philosophical Meaning of Love." In Words of Love and Love of Words in the Middle Ages and the Renaissance, edited by Albrecht Classen, 1-51. Tempe, AZ: Arizona Center for Medieval and Renaissance Studies, 2008.

Cybriwsky, Roman Adrian. Global Happiness: A Guide to the Most Contented (and Discontented) Places Around the Globe. Santa Barbara, CA: Greenwood, 2016.

Dahlberg, Charles. The Literature of Unlikeness. Hanover and London: University Press of New England, 1988.

Domínguez, Patricio. Augustins Philosophiebegriff: Fides und Ratio im Hinblick auf die Glücksfrage (St. Augustine's Concept of Philosophy: Faith and Rationality Regarding the Question About Happiness). Paderborn: Ferdinand Schöningh, 2016.

Doubleday, Simon R. and Coleman, David, ed. In the Light of Medieval Spain: Islam, the West, and the Relevance of the Past. New York: Palgrave Macmillan, 2008.

Evans, Gillian Rosemary. Fifty Key Medieval Thinkers. London and New York: 
Routledge, 2002.

Ikeda, Shinsuke, Kato, Hideaki Kiyoshi, Ohtake, Fumio, and Tsutsui, Yoshiro, ed. Behavioral Economics of Preferences, Choices, and Happiness. Tokyo: Springer Japan, 2016. DOI: 10.1007/978-4-431-55402-8_1.

Karg, Ina. ... «und waz si guoter lêre wernt»...: Mittelalterliche Literatur und heutige Literaturdidaktik-Versuch einer Kooperation (... what are good instructions .... Medieval Literature and Modern Literary Didactics: Attempt of a Cooperation). Frankfurt am Main: Peter Lang, 1998.

Kaylor, Noel Harold. "The English and German Translation Traditions of Boethius's De consolatione philosophiae." Studia Litteraria Universitatis Iagellonicae Cracoviensis 10, no. 1 (2015): 121-129.

Kaylor, Noel Harold, Jr., and Phillips, Philip Edward, ed. A Companion to Boethius in the Middle Ages. Leiden and Boston: Brill, 2012.

Kitanov, Severin. Beatific Enjoyment in Medieval Scholastic Debates: The Complex Legacy of Saint Augustine and Peter Lombard. Lanham, MD: Lexington Books, 2014.

Knäble, Philip. Eine tanzende Kirche: Initiation, Ritual und Liturgie im spätmittelalterlichen Frankreich (A dancing church: initiation, ritual and liturgy in late medieval France). Cologne, Weimar, and Vienna: Böhlau, 2016.

Lindgren, Lauri. Les miracles de Notre Dame de Soissons versifiés: Versifiés par Gautier de Coinci (The Miracles of Our Lady of Soissons: Versified by Gautier de Coinci). Helsinki: Finnish Academy of Science, Series B, 1963.

Marenbon, John, ed. The Cambridge Companion to Boethius. Cambridge and New York: Cambridge University Press, 2009.

Meck, Sabine. Vom guten Leben: eine Geschichte des Glücks (Of Good Life: A History of Good Fortune). Darmstadt: Wissenschaftliche Buchgesellschaft, 2012.

Miedema, Nine and Sieber, Andrea, ed. Zurück zum Mittelalter: Neue Perspektiven für den Deutschunterricht (Back to the Middle Ages: New Perspectives for Teaching of German Literature). Frankfurt am Main: Peter Lang, 2013.

Miller, Jon. The Reception of Aristotle's Ethics. Cambridge: Cambridge University Press, 2012.

Newman, Catherine. Catastrophic Happiness: Finding Joy in Childhood's Messy Years. New York: Little, Brown and Company, 2016.

Pansters, Krijn. Franciscan Virtue: Spiritual Growth and the Virtues in Franciscan Literature and Instruction of the Thirteenth Century. Leiden and Boston: Brill, 2012.

Pollmann, Karla and Otten, Willemien, ed. The Oxford Guide to the Historical Reception of Augustine. Oxford: Oxford University Press, 2013.

Powell, James M. Albertanus of Brescia: The Pursuit of Happiness in the Early Thirteenth Century. Philadelphia: University of Pennsylvania Press, 1992.

Power, Mick. Understanding Happiness: A Critical Review of Positive Psychology. London: Routledge, 2016.

Roberts, Peter. Happiness, Hope, and Despair: Rethinking the Role of Education. 
New York: Peter Lang, 2016.

Rosenberg, Lawrence D., Topol, Deborah A., and Soley, David A. The Trial Lawyer's Guide to Success and Happiness. Chicago: American Bar Association, 2016.

Rudolf von Ems, Der guote Gêrhart, edited by John A. Asher. Tübingen: Max Niemeyer, 1962.

Seppälä, Emma. The Happiness Track: How to Apply the Science of Happiness to Accelerate Your Success. New York: HarperOne, 2016.

Strange, Steven K., and Zupko, Jack, ed. Stoicism: Traditions and Transformations. Cambridge and New York: Cambridge University Press, 2004.

Suldo, Shannon M. Promoting Student Happiness: Positive Psychology Interventions in Schools. New York: Guilford Press, 2016.

Thomä, Dieter, Henning, Christoph, and Mitscherlich-Schönherr, Olivia, ed. Glück: ein interdisziplinäres Handbuch (Happiness: An interdisciplinary manual). Stuttgart: Metzler, 2011. DOI: 10.1007/978-3-476-00372-0.

Ullyot, Jonathan. The Medieval Presence in Modernist Literature: The Quest to Fail. Cambridge: Cambridge University Press, 2015.

von Wolfram, Eschenbach. Parzival and Titurel. Translation and Notes by Cyril Edwards. Oxford: Oxford University Press, 2006.

Waggerl, Karl Heinrich. Wagrainer Tagebuch. Gesammelte Werke, 2 (Wagrain Diary: Collected Works, 2). Salzburg: Otto Müller, 1987.

Warne, Christopher. Aristotle's Nicomachean Ethics: Reader's Guide. London: Continuum, 2007.

Wernicke, Michael Klaus. Glücklich wollen wir mit Sicherheit sein: Augustinus' Suchen nach dem Glauben (We Want to be Happy, for Sure: Augustine's Search for Faith). Würzburg: Echter, 2015.

Zöller, Sonja. Kaiser, Kaufmann und die Macht des Geldes: Gerhard Unmaze von Köln als Finanzier der Reichspolitik und der "Gute Gerhard" des Rudolf von Ems (Emperor, Merchant, and the Power of Money: Gerhard Unmaze of Cologne as Financial Sponsor of Imperial Politics and Rudolf von Ems's "Gute Gerhard"). Munich: Wilhelm Fink Verlag, 1993. 
